\title{
Przebudowa Potsdamer Platz jako przykład współczesnego kształtowania przestrzeni publicznej
}

\author{
Anna Szafranek \\ a.szafranek@pollub.pl \\ Katedra Architektury Wspótczesnej, Wydziat Budownictwa i Architektury, Politechnika Lubelska
}

\begin{abstract}
Streszczenie: Celem artykułu jest zaprezentowanie przestrzeni publicznej, jaką jest Potsdamer Platz, wykreowanej w miejscu o charakterze historycznym i symbolicznym dla Berlina. Przestrzeń ta została zaprojektowana zgodnie z aktualną wiedzą budowlaną i wyobraźnią architektów tak by umożliwić realizację potrzeb współczesnego człowieka. Interesujące może być również odniesienie i porównanie wybranych form zaspokajania potrzeb w przestrzeni publicznej miast w przeszłości do prezentowanego w niniejszym artykule ukształtowania Potsdamer Platz oraz jego bezpośredniego otoczenia. Zaprezentowany rys historyczny dotyczy starożytnej agory i średniowiecznego miasta. Tak nieco rozszerzony temat pozwala na pełniejsze uwypuklenie zmian zachodzących w sposobie kształtowania przestrzeni publicznej. Można się również pokusić o poszukiwanie odpowiedzi na w sposób naturalny nasuwające się pytanie o kierunki zmian w przestrzeni publicznej w przyszłości.
\end{abstract}

Słowa kluczowe: przestrzeń publiczna, Berlin: Potsdamer Platz - Sony Center-Kulturforum, zaspokajanie potrzeb człowieka w przestrzeni publicznej, agora i rynek średniowieczny.

\section{Wstęp}

Place publiczne jako formy przestrzeni publicznej istniały od początku powstawania miast. Wraz ze zwiększającą się ilością mieszkańców zamieszkujących wspólny obszar, nasilały się wzajemne kontakty tych mieszkańców, zarówno te formalne jak i nieformalne. W sposób naturalny pojawiały się ogólnodostępne miejsce, gdzie mieszkańcy mogli przebywać. Miejsca te umożliwiały zaspokajanie różnorodnych potrzeb od banalnego zainteresowania co się dzieje w najbliższym otoczeniu do wywierania wpływu politycznego na funkcjonowanie lokalnej społeczności. Historycznie, w kolejnych stuleciach, wraz z rozwojem miast następowało będące następstwem tego rozwoju poszerzenie granic obszarów miejskich. Rozbudowywały się formy zarządzania i administrowania osadzone w konkretnych warunkach polityczno-ustrojowych swojej epoki. Zmianom towarzyszyły przekształcenia w przestrzeni placów publicznych w ich sferze architektonicznej. Różnorodne funkcje placów publicznych takie jak: handlowe, społeczne (spotkania, rekreacja), reprezentacyjne (gmachy publiczne), komunikacyjne (skrzyżowanie dróg) kształtowały się już od starożytności i umożliwiały realizację potrzeb mieszkańców miasta.

Przestrzeń publiczna jest szczególną formą obiektu architektonicznego wyodrębnionego w przestrzeni miasta. Unikatowość przestrzeni publicznej polega na tym, że budynki tworzące przestrzeń wspólną, użytkowaną zarówno przez jednostki, grupy czy zbiorowości, pozwalają na zaspokojenie potrzeb biologicznych, kulturowych i społecznych. Wallis (1990) zaznacza, że budowle, które nie zaspokajają potrzeb kulturowych nie są zaliczane do architektury. Jest to oczywiście spojrzenie z punktu widzenia socjologicznego i może być ono kontrowersyjne dla architektów. Budynki stają się narzędziami w kształtowaniu przestrzeni wspólnej odpowiadającej za zaspokojenie potrzeb mieszkańców. Potencjał placu publicznego w aspekcie możliwości zaspokojenia potrzeb mieszkańców przekłada się na jego atrakcyjność. Empiryczne badania nad wyodrębnieniem czynników czyniących daną przestrzeń atrakcyjną dla użytkowników wykonano w USA (Whyte W.H. 1979). Cechę atrakcyjności rozumiano jako odbieranie miejsca, które jest lubiane, gdzie ludzie chętnie przebywają, miejsce o uroku i sile 
przyciągania. Badania w sposób pośredni nawiązywały do psychicznych potrzeb zaspokajanych w tej szczególnej przestrzeni jaką jest plac publiczny. Współczesnym przykładem przestrzeni publicznej jest będący przedmiotem niniejszego artykułu zespół budynków w Berlinie przy Potsdamer Platz, na który składają się Sony Center oraz Kulturforum. Przestrzeń publiczną wykreowaną w tym miejscu można śmiało określić jako atrakcyjną. Świadczą o tym choćby liczby zwiedzających: około 80 tysięcy turystów dziennie, zaś w przestrzeni wokół placu pracuje 8 tysięcy osób. (Jałowiecki, Szczepański 2010). Potsdamer Platz w Berlinie jest przykładem nowoczesnej formy kształtowania przestrzeni publicznej. Wynika to między innymi z tego, że został zaprojektowany przez najwybitniejszych współczesnych architektów i przy zastosowaniu najnowszych środków i materiałów stosowanych w budownictwie. Wizje wybitnych architektów, wraz z ogromnymi środkami finansowymi przeznaczonymi na ich realizację przełożyły się na powstanie nowoczesnej przestrzeni ukierunkowanej na zaspokajanie potrzeb rozrywkowo- kulturalnych oraz stworzenie środowiska o twórczym potencjale.

\section{Potsdamer Platz w Berlinie i Sony Center}

\section{Rys historyczny i specyfika miejsca}

Miejsce, na którym znajduje się Potsdamer Platz jest zlokalizowane w centrum Berlina. W tym miejscu w poprzednich wiekach krzyżowały się trakty handlowe. Miejsce było dogodnie usytuowane dla kupców i podróżnych. Wyróżniającym się obiektem była Brama Poczdamska, która z czasem stała się znakiem i symbolem tego miejsca. Rozbudowywane, wyposażane w infrastrukturę (w 1903 - stacja metra, i 4 lata przed II wojną światową stację S-Bahn), nabierało coraz większego znaczenia dla mieszkańców jak i wizytujących gości. W pierwszych dekadach dwudziestego wieku funkcjonował tam Hotel Esplanade, który wyróżniał się na mapie kulturalnej epoki prezentując wydarzenia i osobistości świata kultury. W tamtym czasie na scenie hotelu gościły takie postaci jak Charlie Chaplin czy Greta Garbo. Obie wojny nie oszczędziły hotelu. Zniszczono sam budynek, jak i przy okazji istniejący już ośrodek kultury i życia artystycznego o zasięgu międzynarodowym. Po II Wojnie Światowej dodatkowo powstałe uwarunkowania polityczne dopełniły podziału miasta Berlin i samego Potsdamer Platz. Wspólna część Potsdamer Platz rozdzielona została na dwie części betonową, trzy i półmetrowy zaporą, z wieżyczkami strażniczymi obsadzonymi żołnierzami, mającymi pozwolenie na strzelanie do osób próbujących przekroczyć mur. Mur berliński podzielił fizycznie i społecznie miasto i ludzi mówiącym tym samym językiem i tworzących dotychczas tą samą społeczność lokalną. Obalenie muru berlińskiego w 1989 r. i zjednoczenie Niemiec otworzyło nowe możliwości również dla kreowania wspólnej przestrzeni publicznej miasta. Zmiany polityczne i fizyczne (rozebranie betonowej przegrody) otworzyły nowe możliwości. Obszar Potsdamer Platz wraz z przyległym Alexander Platz jako miejsca historycznie ważne dla Berlina mogły zacząć istnieć jako przestrzeń wspólna dla mieszkańców dotychczas zamieszkujących w dwóch odrębnych rzeczywistościach politycznych, gospodarczych i kulturalnych. Rozpoczęło się nowe życie tego miejsca.

W roku 1990 atrakcyjny duży i rozległy plac, położony w samym w centrum Berlina stanowił wyzwanie dla najlepszych i najbardziej uznanych architektów z Europy i świata. Udział w kształtowaniu wizji i projektowaniu przestrzeni architektonicznej mieli między innymi: Renzo Piano - włoski architekt, Helmuth Jahn - amerykański architekt niemieckiego pochodzenia czy Hans Kollhoff niemiecki architekt, znany z wznoszonych wieżowców. W przebudowie Potsdamer Platz i organizacji na nowo tego miejsca zaangażowały się dwie wielkie korporacje międzynarodowe: Sony oraz Daimler Chrysler (obecnie Daimler AG). W projekcie wykonanym z ogromnym rozmachem, nakreślono bardzo nowoczesne rozwiązania ale też uwzględniono przeszłość miejsca tętniącego kiedyś życiem i rozmachem. Nawiązaniem do przeszłości było uwzględnienie w projekcie wyróżniającego się od początków XX wieku na mapie kulturalnej Europy hotelu Esplanade. Działania wojenne zniszczyły budynek i zdawało się, że bezpowrotnie zakończyły złoty blask poprzedniej epoki. W czasie współczesnej przebudowy Potsdamer Platz postanowiono oddać klimat Belle Epoque, eksponując fragmenty hotelu. Zrekonstruowanym i odnowionym elementem hotelu jest część Sali Cesarskiej wraz z kominkiem, wyeksponowane dla każdej osoby wchodzącej do Sony Center od ulicy Potsdamer Strasse (Ryc. 1). 


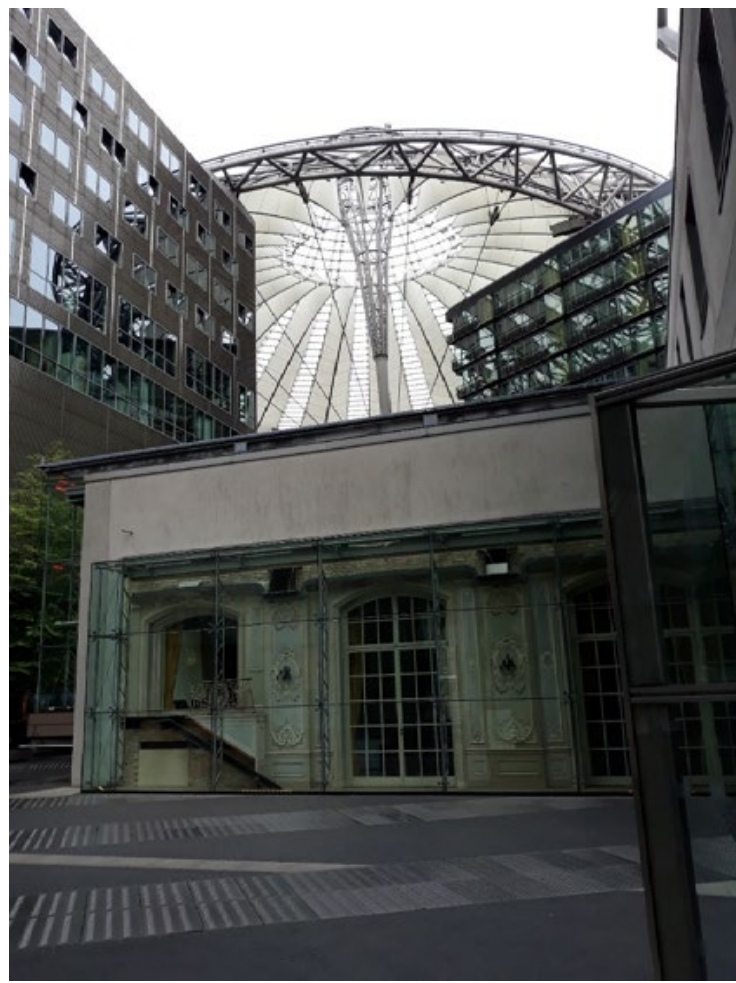

Ryc. 1. Hotel Esplanade - fragmentu ściany hotelu. W tle „parasol” Sony Center. Źródło: A. Szafranek 2018.

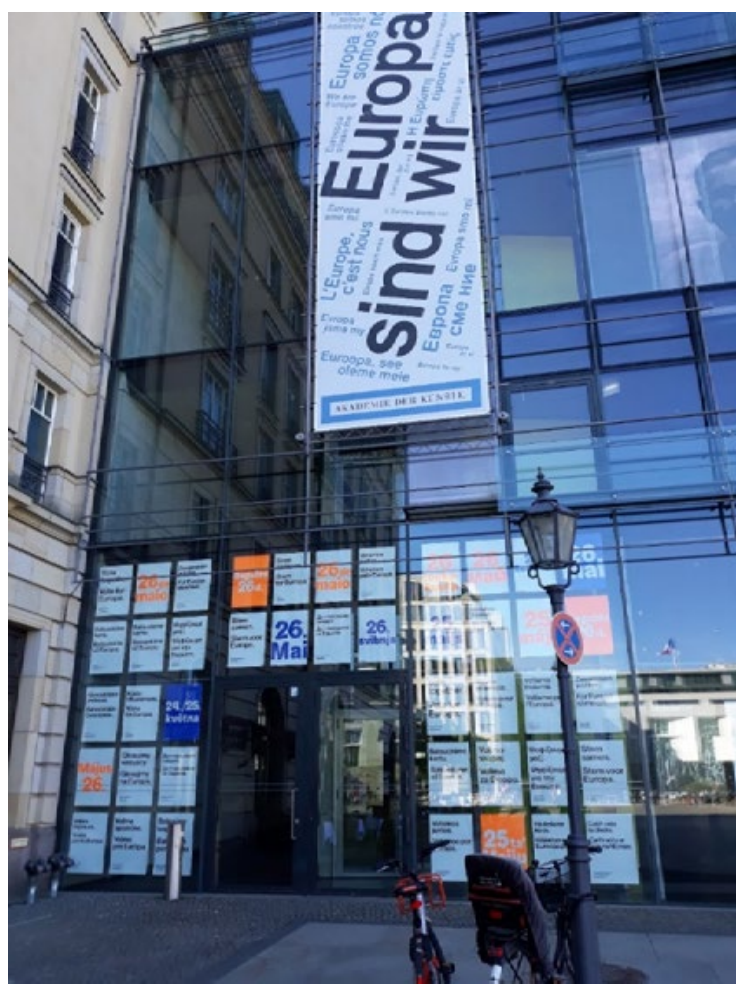

Ryc. 2. Wejście do Akademii Sztuki w roku 2019 przed wyborami do Parlamentu Europejskiego. Źródło: A. Szafranek 2019

Wrażenia wejścia w klimat minionej epoki są wzmacniane wieczorem, kiedy kolorowa gra świateł dodatkowo wydobywa detale i nastraja emocjonalnie do zanurzenia się i poznania przeszłej specyfiki tego miejsca. Fragment muru Sali Cesarskiej stymuluje poznawczo, zachęca do poznania i odrobienia lekcji z przeszłości związanej z tym miejscem. Kolejny aspekt to zaspokajanie potrzeby bycia w miejscu jedynym, unikatowym i zarazem historycznie doświadczanym. Przeprowadzone i opisane wyżej założenie architektoniczne wyzwala psychologiczne poczucie uczestniczenia w ciągłości kultury oraz sprzyja budowaniu tożsamości mieszkańców. Dla świadomych turystów i przyjezdnych czy bywalców w tej przestrzeni, rozszerza horyzonty poznawcze i uruchamia sieć powiązań europejskich. Pozwala kształtować świadomość, że uczestniczenie w kulturze nie jest oddzielane granicami czy przynależnościami narodowymi. Jako inny przykład budowania powiązań europejskich i tworzenia wspólnoty wykraczającej poza ściśle lokalne uwarunkowania można wskazać wystrój frontonu Akademii Sztuki w Berlinie przed wyborami do Parlamentu Europejskiego w 2019 r. Wyartykułowane tam hasło przewodnie brzmi: „Europa to my" i jest wypisane w językach wszystkich krajów tworzących Unię Europejską (Ryc. 2).

\section{Nowoczesne Sony Center}

Fragment Hotelu Esplanade przywołujący życie kulturalne dawnej epoki wprowadza do centralnego miejsca opisywanej przestrzeni publicznej, którym jest Sony Center przykryte spektakularnym „parasolem”. Konstrukcja „parasola" zbudowana została ze szkła i stali i została zaprojektowana przez architekta Yann Kersalé, nazywanego niekiedy artystą światła choć on sam nie lubił tego określenia. (Ryc. 3).

Francuski twórca zaprojektował symulację zachodów słońca poprzez zmianę koloru światła następującą co 21 sekund. W czaszy parasola zmieniające się światło przechodzi z kierunku wschodniego ku zachodniemu. Zastosowanie elementów szklanych i metalowych pozwoliło na wykorzystanie efektu gry światła naturalnego i sztucznego. Poniżej czaszy parasola na kilkunastopiętrowych ścianach budynków otaczających i wyodrębniających część centralną placu wyświetlane są reklamy firmy Sony. Kolorowe zmieniające się światła reklam odbijają się w kopule zbudowanej ze szkła. W tak wykreowanej przestrzeni architektonicznej odbywa się spektakl 
światła. Zaspokaja to psychologiczną potrzebę urozmaicenia, pobudzenia zmysłu wzroku i swoiste uczestniczenie w zabawie kolorami. Zabudowa architektoniczna Sony Center w całości została sfinansowana przez firmę Sony, która również decydowała o całościowym architektonicznym wizerunku tego miejsca. Jest to plac o kształcie owalnym otoczony kawiarniami, restauracjami z otwartymi przestrzeniami zwróconymi ku centrum. Każde z tych miejsc gastronomicznych odznacza się nieco odmiennym stylem: kolorem i formą krzeseł, kształtem stolików, czy ubiorem obsługi. Spożywanie posiłku, wypicie kawy jest nie tylko czynnością zaspokajającą głód, potrzebą z grupy podstawowych ale staje się czynnością społeczną. Klienci lokali uczestniczą również w życiu społecznym i kulturalnym odbywającym się w całej przestrzeni placu. Miejsce w centrum zajmuje fontanna, która przyciąga odwiedzających. Szum wody i wilgoć rozpraszana przez spadającą wodę decyduje o atrakcyjności tego miejsca dla ludzi, nie tylko w upalne letnie dni. Drewniane ławki okalające fontannę stanowią dogodny punkt obserwacji dla turystów i ciekawskich, którzy są obserwatorami ale też są obiektem spojrzeń gości okolicznych kawiarni. Atrakcją placu jest również pianino usytuowane w jego centrum w bliskiej odległości od fontanny. Na pianinie mogą grać wszyscy chętni i odwiedzający często z tej możliwości korzystają (Ryc. 4).

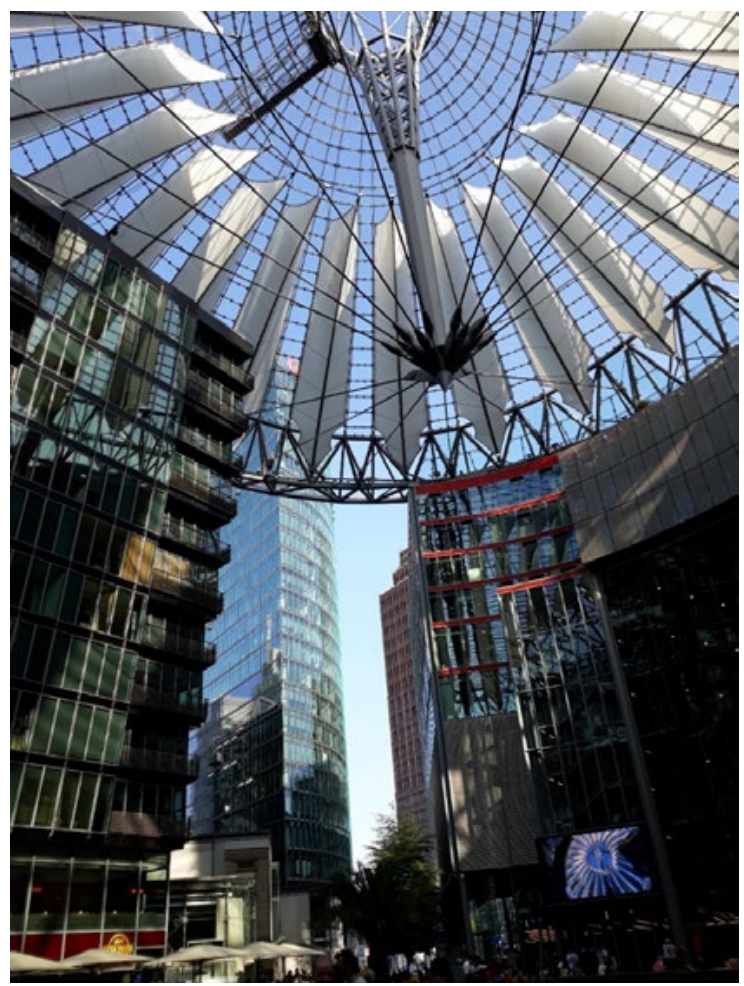

Ryc. 3. Sony Center - widok ogólny. Źródło: A. Szafranek 2019.

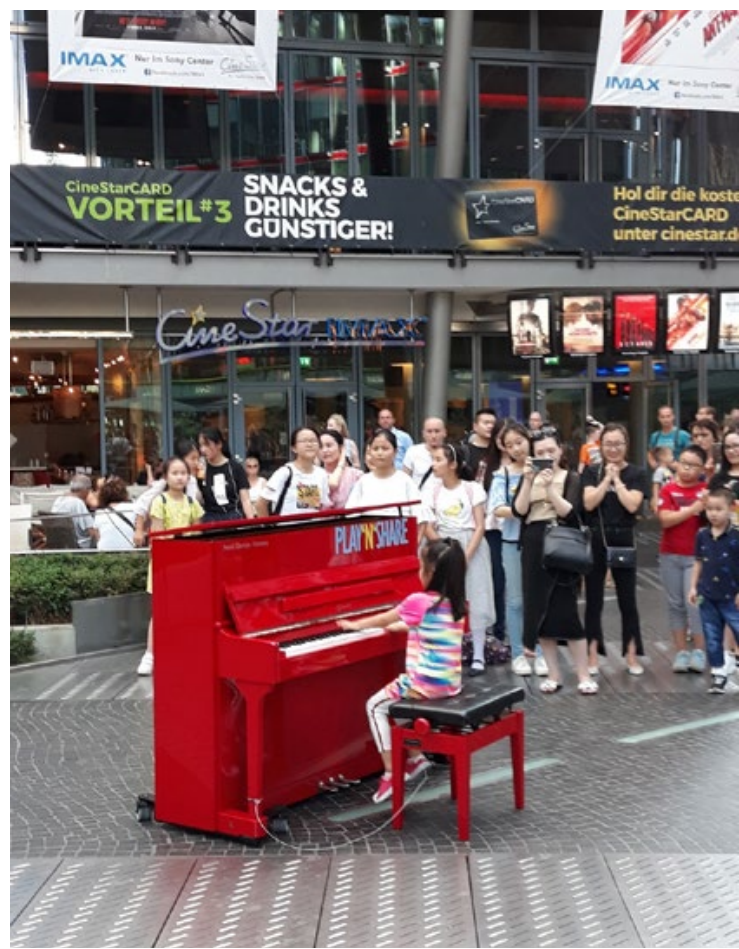

Ryc. 4. Popisy małych i odważnych „artystów” z Azji. Źródło: A. Szafranek 2019.

Instrument muzyczny pełni co najmniej dwie funkcje. Pozwala w sposób bierny, poprzez słuchanie, uczestniczyć w muzycznych popisach mniej lub bardziej biegłych artystów ale również jest okazją do aktywnego uczestnictwa w życiu społecznym toczącym się w obrębie placu. Podkreślenia swojego znaczenia poprzez wyjście z tłumu (bezimiennej zbiorowości) i zaprezentowanie siebie, poprzez grę na pianinie. W obrębie Sony Center funkcjonują również liczne sklepy, kompleks kin oraz w tym miejscu organizowane są wydarzenia artystyczne, kulturalne, rozrywkowe i rekreacyjne np. okresowe lodowisko działające w sezonie zimowym.

\section{Zaspokajanie potrzeb}

Każdy z użytkowników tej publicznej przestrzeni może tu odnaleźć i realizować swoje potrzeby w obszarze stworzonymi poprzez obiekty architektoniczne tworzące kompleks zabudowy Potsdamer Platz i Sony Center. 
Dla jednych użytkowników tej przestrzeni specyfika tego miejsca może być odniesiona do elementu historycznego, dla innych - nowoczesność wyrażona w formie zastosowania współczesnych materiałów pozwalających na wznoszenie lekkich konstrukcji z metalu i szkła, przykładem może być „parasol” zwieńczający i osłaniający całą przestrzeń placu Sony Center.

Dla innych użytkowników tego miejsca przyciągające są wrażenia sensoryczne przeżywane w tym miejscu: szumu wody - fontanny połączonej z dźwiękami pianina, smak dobrej kawy. Widoki ludzi o rysach azjatyckich, europejskich, różnojęzyczny tłum, którego słowa czy zdania wpadają do ucha ze swoją odmiennością brzmienia. Miejsce to porusza wszystkie zmysły dostarczając przyjemności i ponadto buduje świadomość poczucia bycia kimś wyjątkowym poprzez fakt obecności w takim miejscu. Zespalają się różne zaspokajane potrzeby, łączą się i nie muszą być poddawane akademickiej analizie w danym momencie aby poczuć wyjątkowość miejsca i siebie w tym miejscu. Wykreowana przestrzeń uruchamia ciąg skojarzeń poznawczych, ale też emocjonalnych i psychicznych. Możliwość zaspokajania różnorodnych potrzeb decyduje o atrakcyjności miejsca.

\section{Potsdamer Platz w Berlinie i Kulturforum}

Przedłużeniem Sony Center jest kompleks kilku budynków określanych mianem Kulturforum. Obejmuje kilka muzeów takich jak: Gemäldegalerie (Galeria Malarstwa), Kupferstichkabinett (Muzeum Druków i Rysunków), Kunstgewerbemuseum (Muzeum Rzemiosła Artystycznego), i Filharmonię. Każda z tych instytucji stanowi unikatową propozycję dla osób zainteresowanych daną dziedziną sztuki, w tym malarstwem znanych mistrzów, sztychami bądź rysunkami wykonanymi ręką Humboldta, Sandro Botticelli, Dürera, Andy Warhola, rzemiosłem artystycznym czy muzyką.

Lokalizacja budynków muzeów jest rozszerzoną ofertą dla tych, których zainteresowania koncentrują się na potrzebach poznawczych, rozwojowych w dziedzinie sztuki i kultury ale nie tylko.

Słowo muzeum tradycyjnie kojarzy się z ekspozycją wyrobów materialnych z przeszłości. Na obszarze Kulturforum, w przestrzeni pomiędzy budynkami tworzone są okresowe prezentacje współczesnych problemów m.in. ekologicznych. ${ }^{1}$ (Ryc. 5).

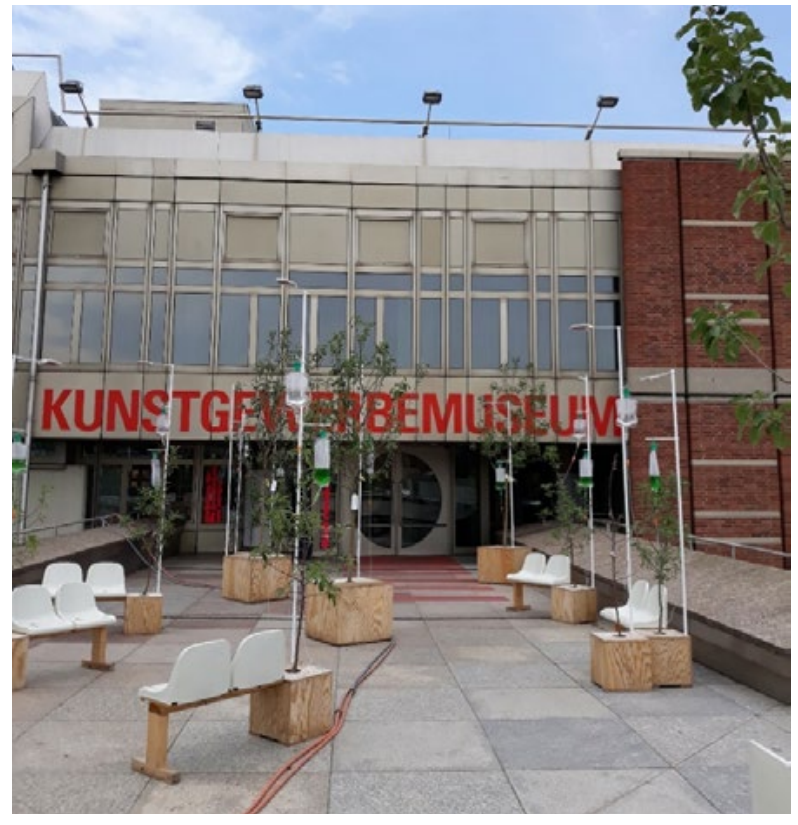

Ryc. 5. Roślinny z podłączonymi „kroplówkami” (2018 rok). Źródło: A. Szafranek 2018.

1 W tym samym czasie w budynku muzeum prezentowano okresową wystawę pokazująca hodowle zwierząt - produkcję mięsa na masową skalę. Można było zobaczyć zdjęcia drobiu, zwierząt hodowlanych trzymanych w klatkach w warunkach sztucznych stworzonych tylko ze względu na cel hodowlany i następnie proces uboju i przetwarzania żywności. Te obrazy zostały skontrastowane z alternatywnym ekologicznym, przyjaznym dla natury sposobem wytwarzania żywności i odżywiana ludności. 
Forma ekspozycji - przedstawienie roślin prawie jak pacjentów ze szpitala, wzbudza zainteresowanie i zatrzymuje uwagę oraz pobudza do myślenia na temat kondycji natury i skutków działań człowieka. Wywołuje refleksje o poczuciu odpowiedzialności i wspólnotowości ludzi w obliczu dobra jakim jest nasza planeta i ograniczony zakres jej zasobów. U osób świadomych głębi zagadnienia wyzwala myśli o przemijalności i o sensie istnienia nas samych. Według koncepcji Sujak (2009) potrzeba sensu zajmuje najwyższą pozycję wśród innych i stanowi zwieńczenie szczytu piramidy potrzeb. Wyrażana w formie pytań np. jaki jest sens mojej obecności, egzystencjalne pytanie po co jestem, filozoficzne zagadnienie mojego bytu i tego kim jestem w tym obecnym świecie, czy mam tylko prawa czy też obowiązki. Jeśli TAK - to jakie? Potrzeba sensu nabiera szczególnego znaczenia w obliczu limitu naturalnych zasobów ziemi. Człowiek i jego sposób korzystania z dóbr naturalnych decyduje o stopniu ich zachowania w obecnej formie i ilości bądź o zmniejszeniu tych zasobów.

\section{Mur Berliński}

Wspomniany wyżej Mur Berliński jako betonowa zapora, o długości 156 km trwał przez 28 lat i przegradzał miasto na dwie części: Berlin Zachodni i Wschodni. Wzniesiony w 1961 roku, w szczególnej sytuacji politycznego podziału Europy na dwa wrogie bloki stał się symbolem dramatu zarówno pojedynczych ludzi (oddzielenia rodzin czy śmierci dla zdesperowanych pragnących przedostać się do Berlina Zachodniego) jak i podziału zbiorowości. Mur był granicą, której przekroczenie wymagało pozwoleń i wiz. Jesień, roku 1989 była świadkiem historycznych wydarzeń. Demokratyczne przemiany w Polsce i masowe demonstracje w Niemczech Wschodnich przyczyniły się do ogłoszenia przez rząd NRD możliwości przekraczania granicy tylko na podstawie dowodu. Ta informacja wywołała coraz większe zgromadzenie ludzi przy przejściach. Tłum stawał się coraz większy. Służby graniczne zdecydowały się przepuszczać ludzi bez sprawdzania dokumentów. W krótkim czasie coraz więcej przejść było otwieranych a następnie mieszkańcy przystąpili do niszczenia muru. W 1990 roku wprowadzono unię walutową i rozpoczął się fizyczny demontaż muru. Pozostawiono kilka fragmentów jako pomniki pamięci. Fragment muru znajduje się również przy wejściu do Potsdamer Platz (Ryc. 6).

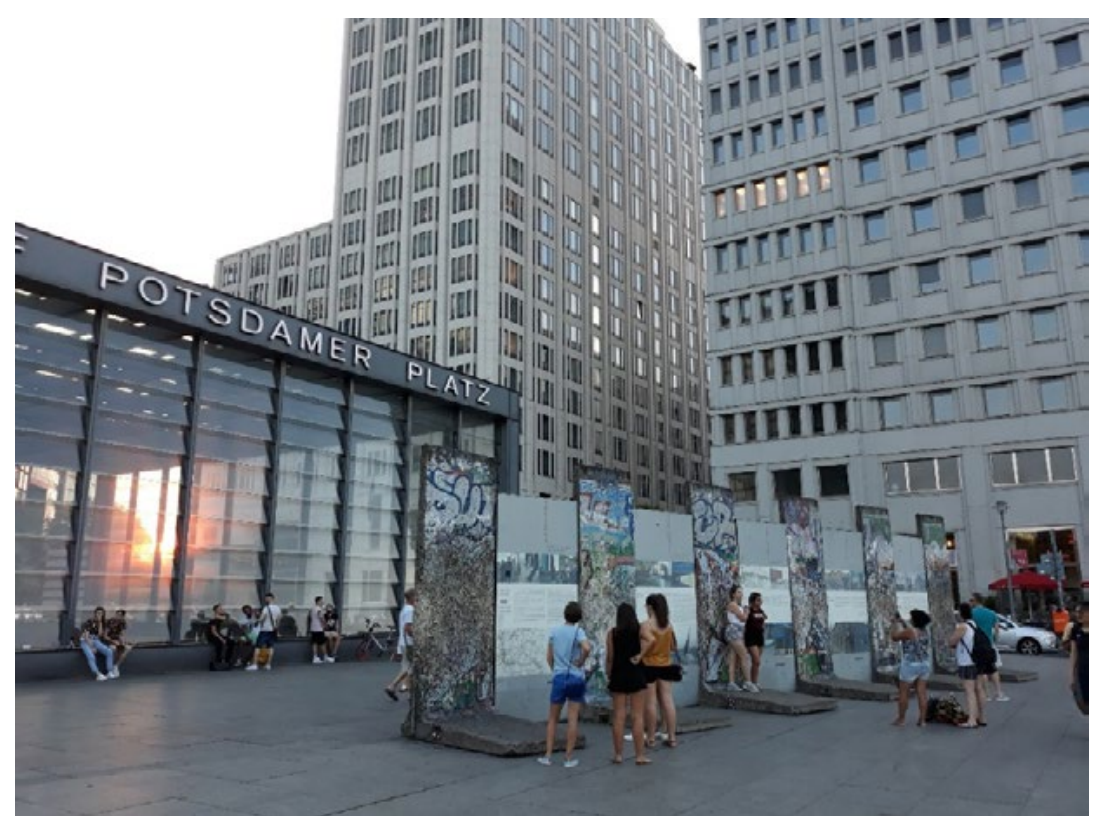

Ryc. 6. Fragment Muru Berlińskiego wyeksponowany przy wejściu do Sony Center. Źródło: A. Szafranek 2018.

Najnowsza historia wita wchodzących do przestrzeni wykreowanej współcześnie. Przypomina o wydarzeniach sprzed kilkudziesięciu lat jak i dramacie ludzi. Jest też symbolem zwycięstwa racjonalności nad autorytarną ideologią. Współcześnie Potsdamer Platz poprzez metro, S-Bahn i komunikacje miejską jest miejscem skomunikowanym z innymi częściami miasta. Szybko i łatwo można dojechać do tego atrakcyjnego miejsca, gdzie możliwe jest wielostronne zaspokajanie potrzeb psychicznych jednostkowych i społecznych. 


\section{Odniesienie do funkcji placów publicznych w przeszłości}

\section{Starożytne Ateny}

Klasycznym miejscem, które można potraktować jako miejsce publiczne jest agora w Starożytnej Grecji. W poprzednich epokach domostwa były skupione wokół jednego budynku (wodza, przywódcy danej społeczności), jak opisują archeolodzy. Osiedla nie posiadały wyodrębnionego obszaru wspólnego. Przykładem mogą być Mykeny - 3,5 tysiąca lat p.n.e. Jakościowo, nowy model osadnictwa z wyodrębnionym obszarem dla wszystkich mieszkańców pojawia się później, w Atenach w V wieku p.n.e. To co wyróżnia to miasto w planie urbanistycznym, to wspólna przestrzeń dla mieszkańców.

Agora, słowo to obecnie jest używane w znaczeniu jako miejsce zgromadzeń, rynek, główny plac. Etymologia

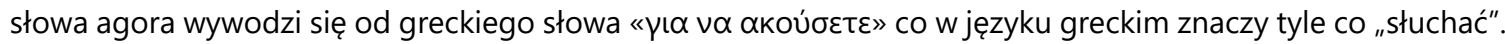
Trzymając się ściśle tego znaczenia słowa, agora bezpośrednio odnosi się do słuchania, rozmowy. Wskazuje na spotkanie ludzi zaangażowanych w dialog. Pośrednio wskazuje na dominujący rodzaj aktywności - kontakty społeczne mieszkańców w tym wyodrębnionym terenie polis miasta - państwa. Rozmowy, wymiany myśli to początek rozwoju polityki i demokracji. Ateny, dotychczasowe jedno z wielu miast polis, zaczyna pełnić rolę centrum kultury dla świata greckiego. To w tym mieście, około 500 roku p.n.e. można było zobaczyć Sokratesa spacerującego po niewielkim placu i zadającego pytania napotykanym ludziom. Czworokątny plac, niebrukowany o powierzchni około 4 ha, stał się świadkiem wymiany słów i idei takich jak "demokracja”, "polityka”, "logika”, "filozofia”, „etyka”, „metoda”, idea”, „system”. Miasto i jego ulice były miejscem spotykania się ludzi i rozwijania dociekliwego myślenia opartego na racjach rozumowych, logicznych. Agora - plac zgromadzeń ludowych stał się miejscem rozstrzygania losów społeczności greckich. Była ona nie tylko miejscem, jakbyśmy współcześnie powiedzieli, kuluarowych rozmów politycznych, ale też miejscem podejmowania decyzji przez Zgromadzenie Ludowe - Eklezję najwyższą władzę w państwie. Agora stanowiła miejsce codziennych spotkań mieszkańców Aten.

Agora stanowiła centrum architektoniczne miasta. Przestrzeń wokół agory lub w jej bliskości zabudowana była budynkami użyteczności publicznej istotnymi dla funkcjonowania państwa. Sąd, heliaja,budynek w którym mieściło się półtora tysiąca osób, beleuterionu - gdzie zbierała się Radu Pięciuset, świątynie, teatr. Budynki były usytuowane w niedalekiej odległości od siebie, dystans można było przejść pieszo. Drogi przecinały się na placu. Obiekty wzniesione wokół placu wpisywały się w całość funkcjonowania miejsca i odpowiadały formie zarządzania państwem. Idea tworzenia państwa zarządzanego przez lud (reforma Klistenesa 594 p.n.e.) wymogła konieczność powstania placu do spotkań i obrad. Demokratyczne formy zarządzania, zgodnie z koncepcją Klistenesa, wyłoniły ciało zwane Radą Pięciuset. Reprezentowała ona po 50 przedstawicieli z 10 obszarów na jakie zostało administracyjnie podzielone terytorium Aten. Rada Pięciuset obradowała w osobnym budynku zwanym beleuterionem o budowie amfiteatralnej, co gwarantowało dobrą akustykę.

W otoczeniu agory znajdował się teatr. Miejsce prezentacji przedstawień od tragedii do komedii oraz ironii i satyry politycznej. Widownia usadowiona na kamiennych siedzeniach, wznoszących się półkoliście wokół sceny zapewniała widoczność i słyszalność. Siedzący nawet na najwyższym ostatnim rzędzie teatru słyszeli słowa wypowiadane na dole. Ateńczycy wykorzystali uwarunkowania akustyczne kamiennej budowli i w pewnym okresie, do teatru przeniesiono obrady Zgromadzenia Narodowego.

Agora była miejscem spotkań indywidualnych, dyskusji, i działań politycznych w demokratycznie zarządzanym państwie. Raz do roku zgromadzenie podejmowało decyzje o ostracyzmie (wydaleniu osoby na 10 lat), która zdaniem obywateli zbyt zagrażała demokracji i jej władza mogła stać się jednowładztwem, tyranią.

Rozwój demokracji odzwierciedlał kształtowanie się agory i wywoływał zmiany w architekturze, powstawaniu nowych budynków, dostosowaniu już istniejących do potrzeb w danym czasie. Sennet (1996) podkreśla jak ważne znaczenie miało miasto, „polis” dla mieszkańców. „Dla Ateńczyka greckie słowo „polis” - miasto takiego Ateńczyka jak Perykles, oznaczało stokroć więcej niż tylko miejsce na mapie; oznaczało miejsce, gdzie ludzie osiągają jedność" (s. 30). Taki pogląd jest wynikiem uczestniczenia w demokratycznych rządach i poczuciu współdecydowania o losach kraju i jego mieszkańców. Fizycznym miejscem, gdzie dochodziło do spotkań, wymiany poglądów, tworzenia wspólnoty była agora. 


\section{Średniowieczny rynek}

Późne średniowiecze to bardzo korzystny okres w historii rozwoju miast. Kształtuje się wtedy autonomia miast, to znaczy decyzje np. przy wyborze przywódcy podejmowane są przy współudziale obywateli, władze miasta są odpowiedzialne za wewnętrzny porządek prawny i regulacje prawno-administracyjne. Miasto jest wolne, gdyż władza nie pochodzi z zewnątrz.

We wczesnym okresie średniowiecza w Europie miasta były niewielkie, ponad 95 \% wszystkich miast do 1500 roku liczyło około dwóch tysięcy mieszkańców (Clarget 1992, za: Jałowiecki, B., Szczepański, M., 2010). Doskonalenie technik produkcji żywności sprawia, że liczebność ludności miejskiej wzrasta. Na podstawie szacunków (por. Wiesiołowski 1997, str. 233) pod koniec XV wieku na przykład miasto Poznań liczyło około 10 tysięcy mieszkańców. Miejscem centralnym zarówno w topografii miasta jak i miejscu życia wspólnotowego dla społeczności mieszkańców staje się rynek. Miejsce to pełniło istotne funkcje: jako centrum handlu i życia społecznego.

Rynek w średniowiecznym mieście to przede wszystkim miejsce handlu lokalnego i dalekosiężnego. Zabudowa rynku była całkowicie podporządkowana przestrzeni targowej. Ukształtowanie rynku, a więc usytuowanie poszczególnych parceli kupców i rzemieślników podporządkowane było pozycji w hierarchii społecznej zawodów i zamożności. W centrum placu znajdowały się parcele krojowników sukna i w kierunkach odśrodkowych mniej zamożnych handlarzy i kupców: kramy szewskie, jatki chlebowe i mięsne czy budników. W bocznych uliczkach znajdowały się wyspecjalizowane targi np. solny, tandeta (targ różnych używanych przedmiotów). Mieszkańcami ścisłego centrum rynku byli przede wszystkim kupcy. ${ }^{2}$

Materialna baza rynku, kramy, parcele, jatki handlowe stanowiła przyczynek i tło dla życia społecznego mieszkańców miasta. Usytuowanie rynku na osi kościół - zamek sprzyjało skupianiu się życia publicznego w tym miejscu. Ta przestrzeń w bliskości kościoła obfitowała w wydarzenia cykliczne organizowane w czasie świąt religijnych bądź sporadyczne wydarzenia organizowane doraźnie. Uczestnictwo mieszkańców miasta w nich dawało poczucia jedności, przeżywania podobnych wydarzeń, budowało poczucie wspólnoty. Na co dzień w przestrzeni okołorynkowej można było spotkać osoby znane, znamienite, np. przedstawicieli patrycjatu kupieckiego, rajców, zamożnych obywateli miasta bądź też ich żony wyróżniające się bogatym strojem wykonanych przez najlepszych ówczesnych krawców i ozdobionym przez mistrzów jubilerstwa. Dla mieszkańca miasta robiącego codzienne zakupy czy akurat przebywającego w tym miejscu, spotkanie znanych osób dostarczało powodu do obserwacji znamienitych obywateli, możliwości komentowania na bieżąco trendów w modzie. Zapewniało uczestnictwo się w „targowisku próżności” tamtego okresu. W czasach obecnych tzw. celebryci pełnią podobną rolę dla wielu współczesnych ludzi bacznie śledzących media społecznościowe i przekaz medialny. Zaspokajana jest potrzebę ciekawości, zainteresowania drugim człowiekiem choćby na poziomie powierzchownym, szukania sensacji. Współcześnie platforma stanowiąca materialne tło wydarzeń społecznych jest inna technicznie, na miarę naszych osiągnięć cywilizacyjnych, ale u podłoża zainteresowania pozostaje zaspokojenie tej samej potrzeby psychicznej: ciekawości, urozmaicenia, przerwania nudy, szukania nowości. W czasach średniowiecznych podobną rolę pełnili wędrowni grajkowie, sztukmistrze, gawędziarze, wędrowne trupy teatralne. Gromadzili wokół siebie ludzi, przyciągali uwagę, zadziwiali. Dostarczali rozrywki. Rynek ówczesny to również rodzaj gazety z wiadomościami z dalekiego świata ale też z lokalnymi. Tutaj wymieniano plotki, nowinki, omawiano skandale jak i decyzje władz. Rysuje się obraz rynku jako miejsca na którym toczy się różnorodne życie nasycone kolorami, zapachami, wielkim bogatym światem. Mające cechy pozwalające na zaspokojenie potrzeb społecznych i kulturalnych.

\section{Przyszłość i kierunek form placów publicznych}

Place publiczne tworzą trwały element wbudowany w strukturę architektoniczną miasta od czasów starożytnych do współczesnych. Wraz ze zmianami cywilizacyjnymi następującymi w kolejnych epokach zmieniał się wygląd placów publicznych jak i zakres form i sposobów zaspokajania przez te place potrzeb człowieka. Ustrój

2 Wiesiołowski ((1997) w swoich analizach historycznych pisze, że wśród mieszkańców rynku przed rokiem 1500, co drugi mieszkaniec zajmowat się handlem, a po 1500 roku 63 \% mieszkańców rynku to byli kupcy i ludzie zajmujący się wymiana handlowa. Ci ludzie zasiadali też we władzach miasta. 
polityczny, formy rządów (demokratyczne, absolutystyczne) i możliwości techniczne wpływały na kształt, formę konstruowania przestrzeni placów, w której mieszkańcy poprzez swoją obecność i aktywność mogli realizować i rozwijać potrzeby psychiczne, społeczne czy kulturalne. Zmieniająca się forma architektoniczna placu publicznego, w następujących kolejno okresach czasu, jest odpowiedzią na możliwości zaspokojenia potrzeb mieszkańców miasta w danym czasie. Trafne dopasowanie formuły placu i odczytanie potrzeb jego mieszkańców zapewnia sukces rozumiany jako atrakcyjność i popularność tej przestrzeni.

Współczesny czas stawia nowe wyzwania. W atrakcyjność placu wpisana jest możliwość zaspokojenia potrzeb współczesnego człowieka. Jedną z nich jest poszukiwanie sfery odpoczynku umożliwiającej również korzystanie z sieci Internet i mediów społecznościowych w obecności lub w współobecności innych ludzi w warunkach odczuwanych jako przyjazne. Oddzielenie od hałasu, odczucie spowolnionego tempa i odcięcie się od miejskiego pędu. Zieleń i woda - te dwa elementy wprowadzające w naturę sprzyjają oderwaniu od rutynowej codzienności z jej niedogodnościami. Dla twórców współczesnej przestrzeni publicznej wyzwaniem powinno być zapewnienie sfery wypoczynku rozumianego jako sposób spędzania czasu rozwijający zainteresowania. Propozycją wbudowaną w taką przestrzeń mogą być obiekty (np. galerie, muzea), lub inne dowolne miejsce, obszary wyzwalające i sprzyjający aktywności twórczej realizowanej w grupie bądź samodzielnie. Idealnie byłoby, gdyby taka forma odpoczynku połączona została z rozrywką.

Unikatowość i wyjątkowość danego miejsca, placu publicznego zawiera się też w jego bryle architektonicznej. Nowoczesne technologie budowlane ułatwiają wznoszenie najbardziej niespotykanych konstrukcji zadziwiających kształtem. Może to być obiekt, rzeźba, budynek, ściana budynku, dach. W przypadku placów publicznych taki spektakularny obiekt jest traktowany jako symbol danego miejsca.

Warto jeszcze wspomnieć, że mieszkaniec dużego miasta zamieszkuje w modernistycznej, rozbitej na monofunkcyjne strefy przestrzeni miasta. Skutkuje to między innymi długimi dojazdami z domu do pracy czy do centrum. Plac publiczny zlokalizowany w odległości umożliwiającej łatwe dotarcie (pieszo lub komunikacją publiczną) jest dla mieszkańców przestrzenią budowania więzi i wspólnoty lokalnej. W kontekście przyszłości placów publicznych, zwłaszcza w dużych ośrodkach miejskich powstanie wielu placów powinno być korzystniejszym rozwiązaniem dla mieszkańców miast niż jednego placu. Uwzględnianie obszarów do publicznego wykorzystania w założeniach urbanistycznych niesie w sobie również aspekt ekonomiczny. Atrakcyjne dla mieszkańców miejsce publiczne, odwiedzane i popularne ma istotny walor ekonomiczny dla zlokalizowanych w pobliżu, sąsiedztwie obiektów handlowych $i$ usługowych. Ujawnia się praktyczna, wymierna i policzalna w pieniądzach strona placów publicznych dla inwestorów wznoszących budynki w pobliżu placu.

llość placów rozrzuconych w różnych częściach miasta to jeden z aspektów. Kolejnym jest forma, która różni się do tradycyjnie pojmowanego placu jako obszaru otoczonego budynkami. Współcześnie, wraz z wznoszeniem budynków wysokich i bardzo wysokich, coraz częściej wykorzystuje się ich dachy jako powierzchnię użytkową. Dach zostaje przeznaczony oraz zagospodarowany jako obszar wypoczynkowo-rozrywkowy. Zieleń, miejsca do posiedzenia czy inne obiekty realizujące pomysły architektów wypełniają tą przestrzeń. Nadają jej charakter wypoczynkowy bądź rozrywkowy, sprzyjając spotykaniu się ludzi, budowaniu więzi i wzmacnianiu wzajemnych kontaktów.

\section{Podsumowanie}

W artykule zaprezentowano przestrzeń Potsdamer Platz i jego otoczenia. W tym przedstawieniu zaprezentowano nowoczesne rozwiązania z uwzględnieniem aspektów historycznych związanych z tym miejscem. Architektoniczne bryły i wyposażenie placu przedstawiono jako tło dla możliwości realizacji potrzeb współczesnego człowieka. W przestrzeni placu rozwija się swoisty dialog pomiędzy człowiekiem i oferowanymi mu rozwiązaniami architektonicznymi. Wzbogaceniem dwutorowości i współdziałania tych dwóch bytów jest analiza historyczna miejsc publicznych, wspólnie dzielonych przez społeczność w okresie Starożytnej Grecji i średniowiecza. Pierwsza z nich Agora w Grecji ma szczególne miejsce w historii jako kolebka demokracji. Drugie miejsce - rynek średniowieczny zyskuje swoje szczególne miejsce ze względu na początek funkcji jakie w późniejszym okresie zostały w pełni rozwinięte i uzyskały samodzielność w wyodrębnianych przestrzeniach publicznych miast. Obecna forma Potsdamer Platz i jego otoczenia jest przykładem przestrzeni publicznej która oferuje współczesnemu człowiekowi możliwość zaspokajania potrzeb zarówno indywidualnych jak i społecznych, kulturalnych i rekreacyjnych. 
Istnienie człowieka na poziomie psychologicznym wiąże z realizacją potencjału intelektualnego i estetycznego i Maslow nazywa je potrzebą samorealizacji, najwyższej umieszczoną w hierarchii (Maslow $(2004,2018)$. Szeroka oferta zawarta w formie architektonicznej skierowana jest do różnorodnych pod względem zainteresowań i wieku bywalców tej przestrzeni. Przedstawione w artykule odniesienia historyczne pokazują, że część funkcji placów publicznych nie uległa zmianie. Realizowane są te same potrzeby psychiczne człowieka jednak przy wykorzystaniu zupełnie innych środków uwarunkowanych nowymi możliwościami technicznymi. Następuje wyraźne przesunięcie potrzeb zaspokajanych przestrzeniach publicznych w kierunku kultury, rozgrywki i rekreacji.

\section{Literatura}

[1] Jałowiecki, B., Szczepański M., Miasto i przestrzeń w perspektywie socjologicznej. Wydawnictwo Naukowe SCHOLAR, Warszawa 2010.

[2] Maslow A.H., Motywacja i osobowość, Wydawnictwo Naukowe PWN, Warszawa 2018.

[3] Maslow A.H., W stronę psychologii istnienia, Wydawnictwo „Rebis”, Poznań 2004.

[4] Sennet R., Ciało i kamień, Wydawnictwo „Marabut”, Gdańsk 1996.

[5] Sujak E., ABC psychologii komunikacji, Wydawnictwo WAM, Kraków 2009.

[6] Wallis A. Socjologia przestrzeni, Niezależna Oficyna Wydawnicza, Warszawa 1990.

[7] Whyte W.H., The Social Life of Small Urban Space, a film by William H. Whyte. Produced by The Municipal Art Society of New York 1979.

[8] Wiesiołowski J., Socjotopografia późnośredniowiecznego Poznania. Wydawnictwo Poznańskiego Towarzystwa Przyjaciół Nauk, Poznań 1997. 